\title{
Surveilan Kesehatan Masyarakat: \\ Program Pencegahan Dan Pengendalian Penyakit Demam Berdarah Dengue Di Kota Cimahi
}

\author{
Budiman $^{1 *}$, Herly Oetami ${ }^{2}$ \\ STIKES Jenderal Achmad Yani Cimahi \\ 1e-mail: budiman_1974@yahoo.com \\ 2e-mail: herlykaka22@gmail.com \\ *Corresponding Author
}

\begin{abstract}
ABSTRAK
DBD merupakan penyakit endemis yang dapat terjadi di berbagai wilayah dan sepanjang tahun. Program pencegahan dan pengendalian DBD sangat penting untuk dilakukan sebagai bentuk penanganan kasus DBD dan pengendalian vektor serta program tersebut harus dievaluasi untuk mengetahui bagaimana program tersebut dapat berjalan. Pengabdian masyarakat ini bertujuan mengetahui gambaran program pencegahan dan pengendalian penyakit DBD di Dinas Kesehatan Kota Cimahi. Metode yang dilakukan adalah analisis deskriptif epidemiologi serta evaluasi perencanaan program kesehatan. Hasil analisis menunjukkan kasus DBD tahun 2019 sebanyak 1020 kasus (IR 189,75) dan persentase ABJ 89\%. Program P2DBD yang dilakukan terfokus pada kegiatan fogging dan lomba PSN masyarakat. Diketahui efektivitas intervensi pada program P2DBD terhadap CFR DBD 160\%, terhadap IR DBD -187,24\%, dan terhadap keberhasilan ABJ 93,68\%. Efisiensi dari program P2- DBD terhadap CFR 40\%, terhadap IR DBD 387,2\%, dan ABJ 93,68\%. Dapat disimpulkan bahwa program fogging dan lomba PSN efektif terhadap peningkatan persentase ABJ atau penurunan keberadaan vektor. Maka dari itu, disarankan agar kegiatan PSN melalui pemberdayaan masyarakat dapat lebih ditingkatkan.
\end{abstract}

Kata Kunci: Program Pencegahan, Pengendalian Demam Berdarah Dengue

\begin{abstract}
DHF is an endemic disease that can occur in various regions and throughout the year. DHF prevention and control programs are very important to be carried out as a form of handling dengue cases and vector control and the program must be evaluated to find out how the program can work. This community service aims to determine the description of the DHF prevention and control program at the Cimahi City Health Office. The method used is descriptive epidemiological analysis and evaluation of health program planning. The analysis showed that there were 1020 dengue cases in 2019 (IR 189.75) and the percentage of ABJ was 89\%. The P2DBD program is focused on fogging activities and community PSN competitions. It is known that the effectiveness of the intervention in the P2-DBD program on CFR DHF is $160 \%$, against IR DHF $-187.24 \%$, and on the success of ABJ 93.68\%. The efficiency of the P2-DBD program against CFR 40\%, against IR DBD 387.2\%, and ABJ 93.68\%. It can be concluded that the fogging program and PSN competition were effective in increasing the percentage of $A B J$ or decreasing the presence of vectors. Therefore, it is suggested that PSN activities through community empowerment can be further improved.
\end{abstract}

Keywords: Prevention Programs, Dengue Hemorrhagic Fever Control 


\section{PENDAHULUAN}

Demam berdarah dengue (DBD) merupakan penyakit infeksi menular yang disebabkan virus dengue (arbovirus) yang ditularkan melalui gigitan nyamuk Aedes betina terutama Aedes Albopictus atau Aedes Aegepty(Purnama, 2017). Penularan DBD dapat terjadi melalui gigitan nyamuk yang mengandung virus dengue baik Den 1, Den 2, Den 3, dan Den 4 yang dapat ditemukan di berbagai daerah di Indonesia. Den 1 dan Den 3 merupakan tipe virus dengue yang banyak berkembang di masyarakat (Arsin, 2013).

Penyakit DBD sering muncul dan berkembang di daerah tropis dan subtropis di berbagai belahan dunia, terutama di musim hujan yang lembap. Indonesia merupakan salah negara tropis di Asia tenggara dengan suhu, kelembaban dan curah hujan relatif tinggi. Keadaan tersebut menjadi tempat ideal bagi habitat perkembangan vektor penular penyakit seperti nyamuk Aedes penyebab demam berdarah dengue (Chin, 2012).

DBD merupakan salah satu penyakit yang dapat memicu terjadinya kejadian luar biasa (KLB) bahkan wabah dan menyebabkan kematian. KLB DBD dapat terjadi hampir setiap tahun di beberapa wilayah dengan tempat yang berbeda dan kejadiannya sulit diduga. Hampir seluruh Kab/Kota di Indonesia merupakan wilayah endemis DBD. Sejak ditemukan pertama kali tahun 1968 di Jakarta dan Surabaya, saat ini penyebaran DBD semakin meluas dan mencapai seluruh provinsi di Indonesia (Kemenkes RI, 2017a).Kasus DBD di Indonesia tahun 2018 sebanyak 65.602 kasus, angka kesakitan (Incident Rate-IR) 24,75 per 100.000 penduduk, jumlah kematian 467 orang dengan Case Fatality Rate (CFR) 0,71\%. Jawa Barat menempati urutan pertama dengan jumlah kasus DBD tertinggi di Indonesia pada tahun 2018 sebanyak 8.732 kasus (IR 17,94), 49 orang meninggal (tertinggi kedua) dengan CFR 0,56\% (Kemenkes RI, 2019; Dinkes Jawa Barat, 2018).

Kota Cimahi termasuk salah satu wilayah endemis DBD di Jawa Barat. Kasus DBD tahun 2016 sebanyak 1080 kasus (IR 182) menyebabkan 6 orang meninggal (CFR 0,6) dan dinyatakan sebagai KLB. Tahun 2017 sebanyak 313 kasus (IR 51) dan tahun 2018 sebanyak 292 kasus (IR 49,2) (Dinkes Kota Cimahi, 2019). Tahun 2019 diketahui kasus DBD sebanyak 1020 kasus (IR 189,75), dimana 4 orang meninggal (CFR 0,39). Penyakit DBD diperkirakan akan masih cenderung terus meningkat dan meluas dalam pola penyebarannya (Kemenkes RI, 2017b). Hal tersebut dapat disebabkan karena adanya peningkatan populasi vektor penular DBD disertai meningkatnya tempat perindukan vektor yang tersebar luas baik di tempat pemukiman maupun di tempat umum (Dinkes Kota Cimahi, 2018).

Terdapat berbagai faktor yang dapat mempengaruhi kasus DBD, baik dari agent (vektor/ nyamuk), host (pejamu/ perilaku manusia), maupunenvironment (lingkungan yang mendukung 
perkembanganbiakan nyamuk) yang bilamana tanpa pengendalian dan penangan yang cepat dapat menyebabkan KLB maupun wabah dan berisiko tinggi meningkatkan angka kematian(Setiati et al., 2014; Kemenkes RI, 2017b; Purnama, 2017).Berbagai upaya pengendalian kasus DBD khususnya pada daerah dengan transmisi yang tinggi atau persisten sangat diperlukan. Daerah yang memiliki transmisi tinggi DBD adalah wilayah Kota/Kabupaten dengan IR tinggi sehingga membutuhkan pengendalian penyakit yang teliti dan cepat (Qi et al., 2015).

Program pencegahan dan pengendalian DBD diarahkan pada upaya memutus rantai penularan sehingga dapat mencegah jumlah kesakitan, kematian, dan menekan penyebaran kasus. Upaya pencegahan kasus kematian dilaksanakan dengan penemuan kasus secara dini, pelaporan cepat, dan diikuti tatalaksana kasus (Kemenkes RI, 2017b).

Upaya pencegahan dan pengendalian DBD diarahkan pada upaya pemutusan mata rantai penularan antara manusia-nyamuk-manusia dengan pemberantasan sarang nyamuk, membunuh nyamuk dewasa, mengetahui faktor-faktor yang memungkinkan timbulnya penyakit, serta intervensi yang dilakukan. Upaya pencegahan DBD saat ini masih menggunakan metode Pemberantasan Sarang Nyamuk (PSN) melalui kegiatan 3M Plus dengan pemberdayaan masyarakat yang dilaksanakan melalui pendekatan Gerakan 1 Rumah 1 Jumantik (G1R1J) dan juga di lingkungan sekolah. Upaya PSN 3M Plus adalah seluruh kegiatan masyarakat bersama pemerintah untuk mencegah dan mengendalikan DBD dengan melakukan PSN terus menerus dan berkesinambungan. Walaupun demikian, kasus DBD dapat terus meningkat seiring dengan kurang aktifnya masyarakat dalam pelaksanaan 3M Plus, sehingga dilakukan pengendalian vektor sebagai langkah terakhir,yaitu dengan melakukan pencegahan secara kimiawi menggunakan Fogging (Dinkes Kota Cimahi, 2018).

Pada pengabdian ini, kami berupaya membantu Pemerintah Kota Cimahi dalam mengevaluasi pelaksanaan program pencegahan dan pengendalian penyakit DBD, sehingga dapat dilakukan perbaikan maupun pengembangan dalam usaha mencegah peningkatan kasus DBD. Tujuan pengabdian masyarakat adalah melakukan surveilans kesehatan masyarakat program pencegahan dan pengendalian penyakit DBD di Kota Cimahi.

\section{BAHAN DAN METODE}

Pada pelaksanaan kegiatan pengabdian ini dilaksanakan pada bulan Januari 2020 di bagian Pencegahan dan Pengendalian Penyakit (P2P) seksi P2P Menular (P2PM) Dinas Kesehatan Kota Cimahi. Adapun bahan yang digunakan adalah landasan pusataka terkait dengan Demam Berdarah Dengue dan hasil laporan kasus DBD di Kota Cimahi tahun 2019 serta hasil wawancara dengan bidang P2P DBD P2PM Dinkes Kota Cimahi. 
Penyakit DBD merupakan penyakit demam akut yang disebabkan oleh penularan serotipe virus dengue oleh nyamuk Aedes aegypti. Virus dengue yang termasuk kelompok B Arthopod Borne Virus (Arboviroses) yang sekarang dikenal sebagai genus Flavivirus, famili Flaviviricae, dan mempunyai 4 jenis serotipe yaitu : DEN-1, DEN-2, DEN-3, DEN-4. Infeksi salah satu serotipe akan menimbulkan antibodi terhadap serotipe yang bersangkutan, sedangkan antibodi yang terbentuk terhadap serotipe lain sangat kurang, sehingga tidak dapat memberikan perlindungan yang memadai terhadap serotipe lain. Serotipe DEN-3 merupakan serotipe yang dominan dan diasumsikan banyak yang menunjukkan manifestasi klinik yang berat (Hadinegoro, dkk. 2001).

Vektor penyakit DBD adalah nyamuk jenis Aedes aegypti dan Aedes albopictus terutama bagi Negara Asia, Philippines dan Jepang, sedangkan nyamuk jenis Aedes polynesiensis, Aedes scutellaris dan Aedes pseudoscutellaris merupakan vektor di negara-negara kepulauan Pasifik dan New Guinea. Vektor DBD di Indonesia adalah nyamuk Aedes (Stegomya) aegypti dan albopictus (Djunaedi, 2006).

Penyakit ini ditandai dengan empat gejala klinis utama yakni demam tinggi, manifestasi perdarahan, hepatomegali, dan tanda-tanda kegagalan sirkulasi sampai timbulnya renjatan (sindrom renjatan dengue) sebagai akibat dari kebocoran plasma yang dapat menyebabkan kematian (Depkes RI, 2010).

Penularan penyakit DBD memiliki tiga faktor yang memegang peranan pada penularan infeksi virus, yaitu manusia, virus dan vektor perantara (Hadinegoro, dkk. 2001). Lebih jelasnya Depkes RI, 2005 menjelaskan mekanisme penularan penyakit DBD dan tempat potensial penularannya:

1. Mekanisme Penularan DBD

Seseorang yang di dalam darahnya mengandung virus dengue merupakan sumber penular DBD. Virus dengue berada dalam darah selama 4-7 hari mulai 1-2 hari sebelum demam. Bila penderita DBD digigit nyamuk penular, maka virus dalam darah akan ikut terhisap masuk ke dalam lambung nyamuk. Selanjutnya virus akan memperbanyak diri dan tersebar di berbagai jaringan tubuh nyamuk, termasuk di dalam kelenjar liurnya. Kira-kira 1 minggu setelah menghisap darah penderita, nyamuk tersebut siap untuk menularkan kepada orang lain (masa inkubasi ekstrinsik). Virus ini akan berada dalam tubuh nyamuk sepanjang hidupnya. Oleh karena itu, nyamuk Aedes aegypti yang telah menghisap virus dengue menjadi penular sepanjang hidupnya. Penularan ini terjadi karena setiap kali nyamuk menusuk (menggigit), sebelumnya menghisap darah akan mengeluarkan air liur melalui alat tusuknya (proboscis), agar darah yang dihisap tidak membeku. Bersamaan air liur tersebut virus dengue dipindahkan dari nyamuk ke orang lain. 
2. Tempat potensial bagi penularan DBD

Penularan DBD dapat terjadi di semua tempat yang terdapat nyamuk penularnya. Oleh karena itu tempat yang potensial untuk terjadi penularan DBD adalah:

a. Wilayah yang banyak kasus DBD (rawan/endemis).

b. Tempat-tempat umum yang menjadi tempat berkumpulnya orang-orang yang datang dari berbagai wilayah sehingga kemungkinan terjadinya pertukaran beberapa tipe virus dengue yang cukup besar seperti: sekolah, RS/Puskesmas dan sarana pelayanan kesehatan lainnya, tempat umum lainnya (hotel, pertokoan, pasar, restoran, tempat ibadah dan lain-lain).

c. Pemukiman baru di pinggir kota, penduduk pada lokasi ini umumnya berasal dari berbagai wilayah maka ada kemungkinan diantaranya terdapat penderita yang membawa tipe virus dengue yang berbeda dari masing-masing lokasi.

Metode yang digunakan adalah sistem pelaporan rutin, dimana pengumpulan data dilakukan dengan data sekunder yaitu data kasus DBD dan hasil laporan kegiatan DBD serta wawancara. Adapun hasil data dianalisis secara deskriptif epidemiologi untuk mengetahui bagaimana trend kasus DBD sehingga diperoleh gambaran umum mengenai kasus DBD yang terjadi di Kota Cimahi dan mengetahui program atau kegiatan pencegahan dan pengendalian DBD yang dilakukan oleh Seksi P2PM Bidang P2P Dinas Kesehatan Kota Cimahi. Selanjutnya kegiatan yang telah dilakukan dianalisis untuk diketahui bagaimana efektivitas dan efisiensi serta mendeskripsikan berbagai kegiatan yang telah dilakukan yang disesuaikan dengan program perencanaan epidemiologi.

\section{HASIL DAN PEMBAHASAN}

\section{Analisis Situasi Data Kasus DBD di Kota Cimahi Tahun 2019}

Berikut kami sajikan hasil analisis data kasus DBD yang terjadi di Kota Cimahi sepanjang tahun 2019 yang dilakukan secara deskriptif epidemiologi yaitu menurut waktu (trend berdasarkan bulan dan tahun), menurut demografi (jenis kelamin dan umur), serta menurut tempat (Puskesmas). 


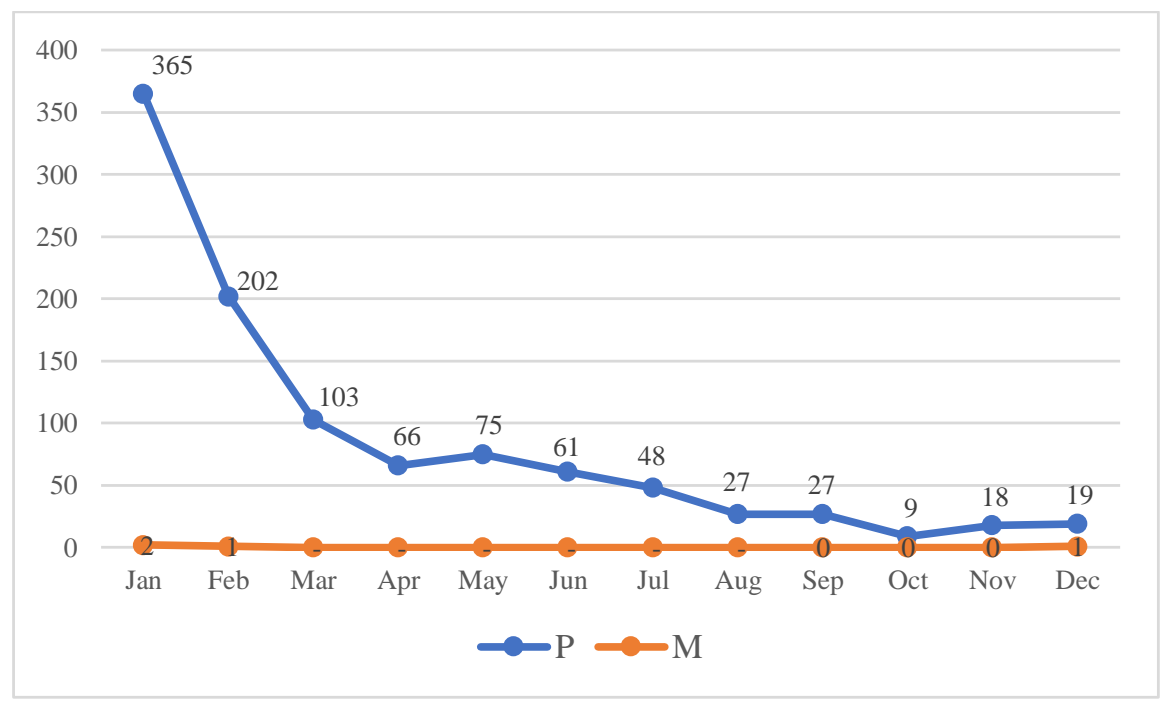

Gambar 1 Grafik Kasus DBD Per Bulan Di Kota Cimahi Tahun 2019

Diketahui kasus puncak DBD terjadi di bulan Januari 2019sebanyak 365 kasus, kemudian mengalami penurunan sampai bulan Oktober, dan meningkat di bulan November-Desember 2019.

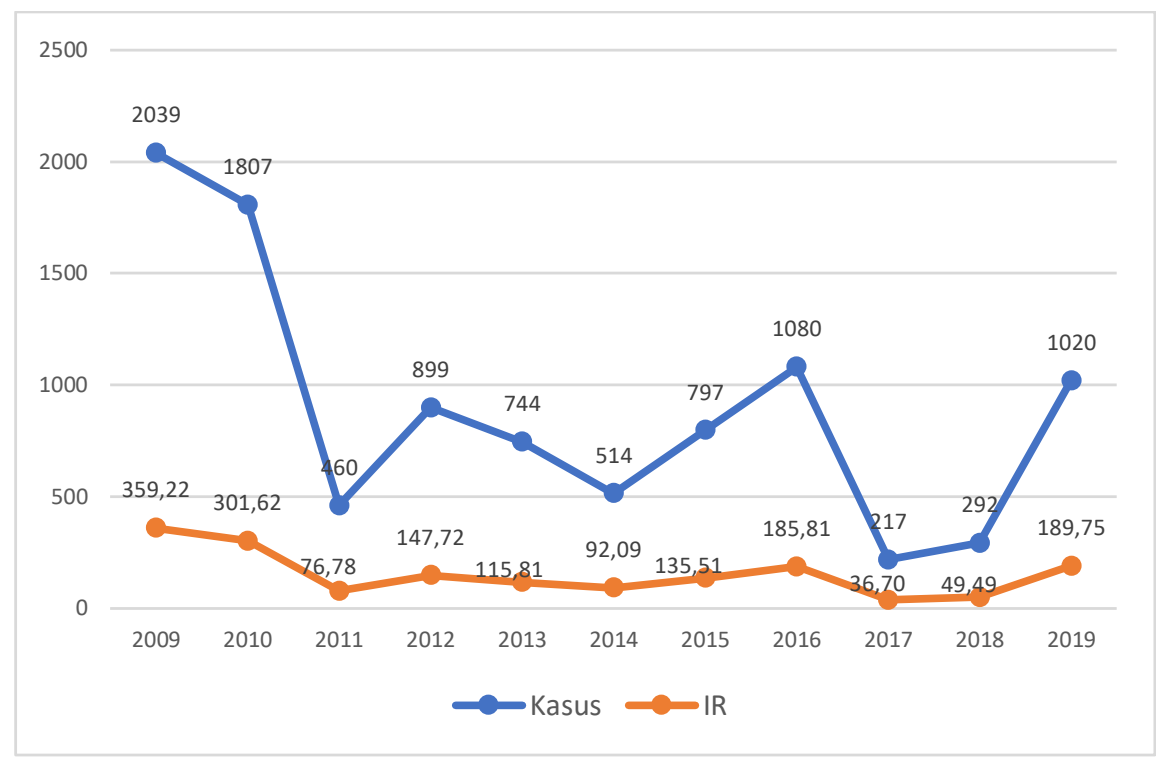

Gambar 2 Grafik Kasus dan Incidente Rate (IR) DBD dalam 10 Tahun Terakhir di Kota Cimahi

Kasus DBD dan IR tertinggi terjadi di tahun 2009 (2039 kasus; IR 359,22), tahun 2010 (1807 kasus; IR 301,62), tahun 2016 (1079 kasus; IR 184,61), tahun 2019 (1020 kasus; IR 189,75). Dilihat dari pola kasus DBD, diketahui tahun 2009 merupakan kasus dan IR DBD tertinggi, tahun 2010-2011 mengalami penurunan kasus dan kembali meningkat di tahun 2012. Tahun 2013-2014 mengalami penurunan dan meningkat di tahun 2015 serta puncak kasus tertinggi terjadi di tahun 2016. Kasus DBD tahun 2017-2018 mengalami penurunan dan meningkat kembali di tahun 2019. 


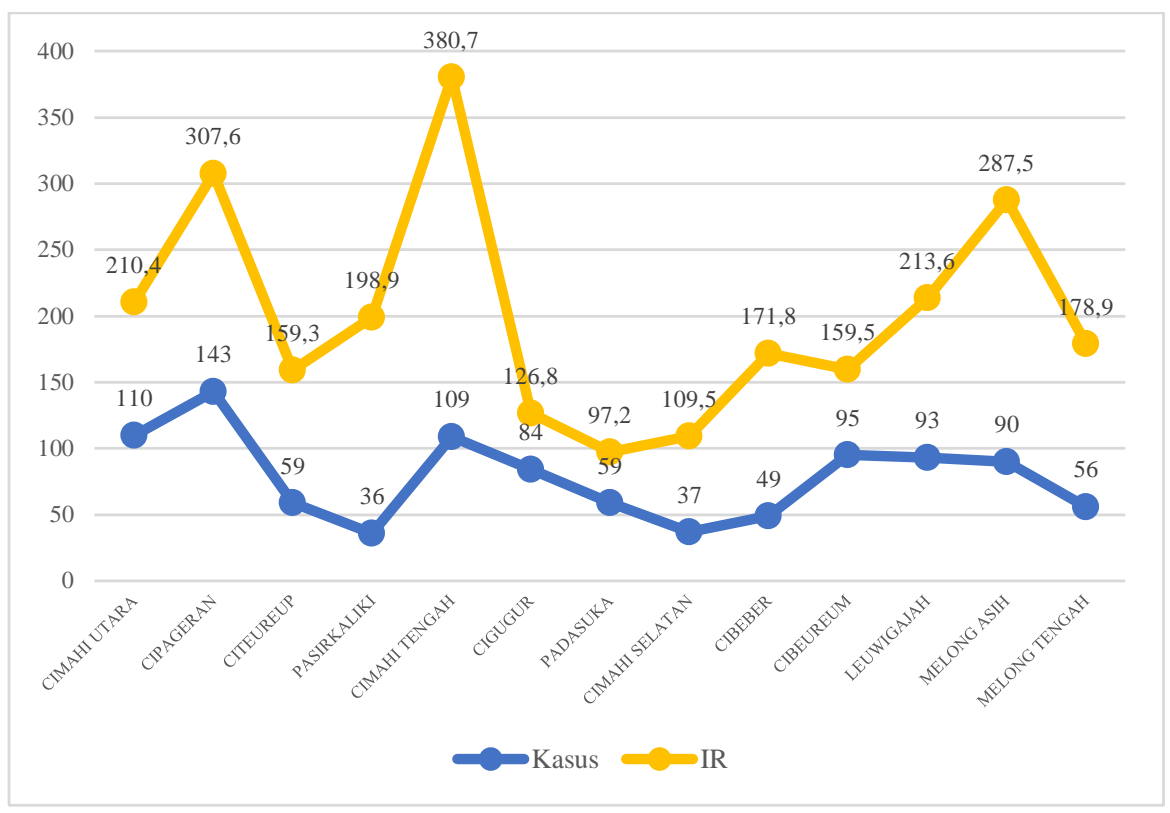

Gambar 3 Grafik Kasus dan Incidente Rate (IR) DBD Berdasarkan Wilayah Puskesmas di Kota Cimahi Tahun 2019

Diketahui bahwa kasus DBD tertinggi terjadi di Puskesmas Cipageuran yaitu 143 kasus, sedangkan IR DBD tertinggi yaitu di Puskesmas Cimahi Tengah 380,7\%.

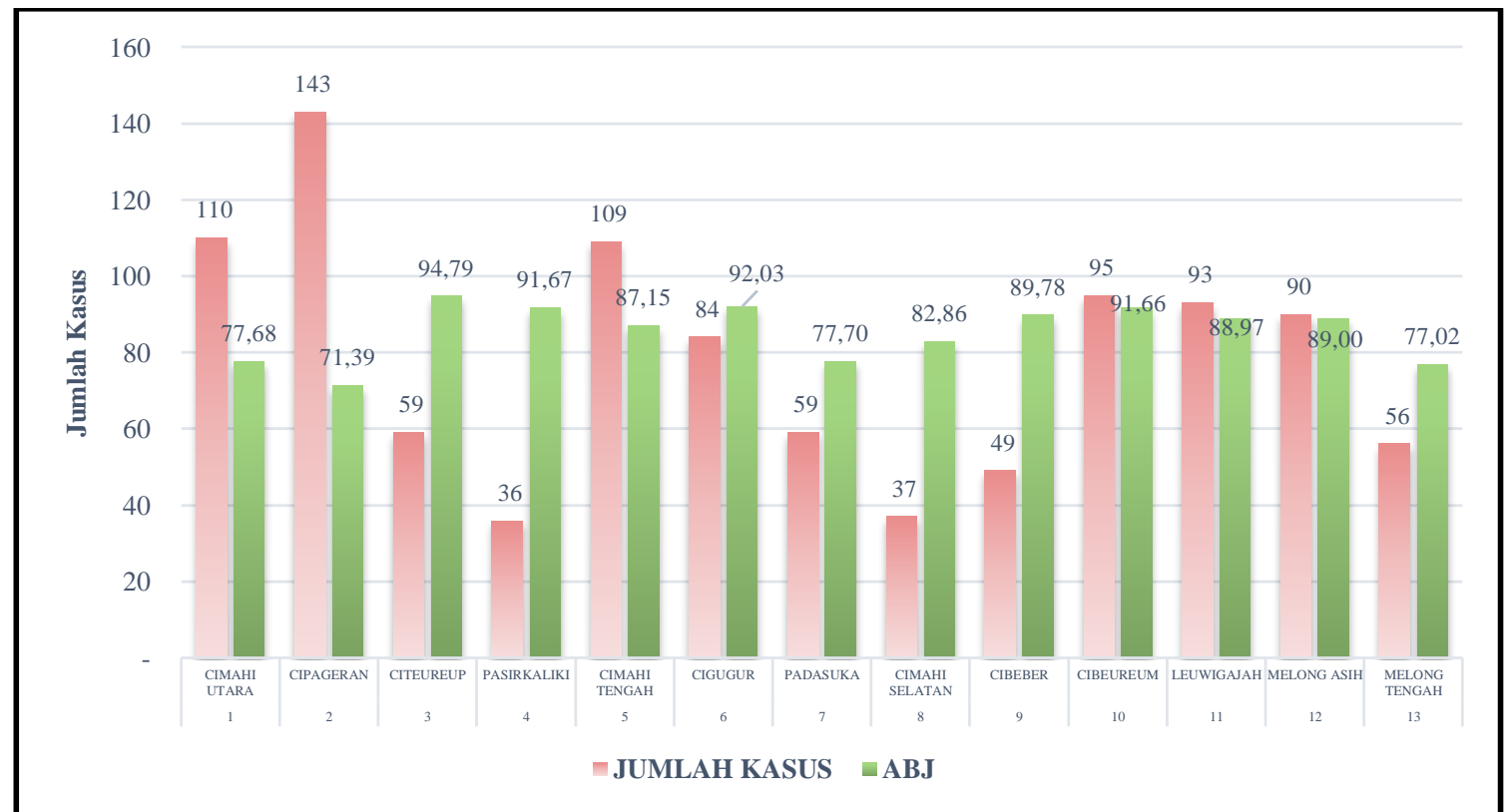

Gambar 4. Grafik Kasus DBD dan Angka Bebas Jentik Per Puskesmas di Kota Cimahi Tahun 2019

Diketahui bahwa ABJ tertinggi di Puskesmas Citeureup 94,79\% (59 kasus), dan ABJ terendah di Puskesmas Cipageuran sebesar 71,39\% (143 kasus). 


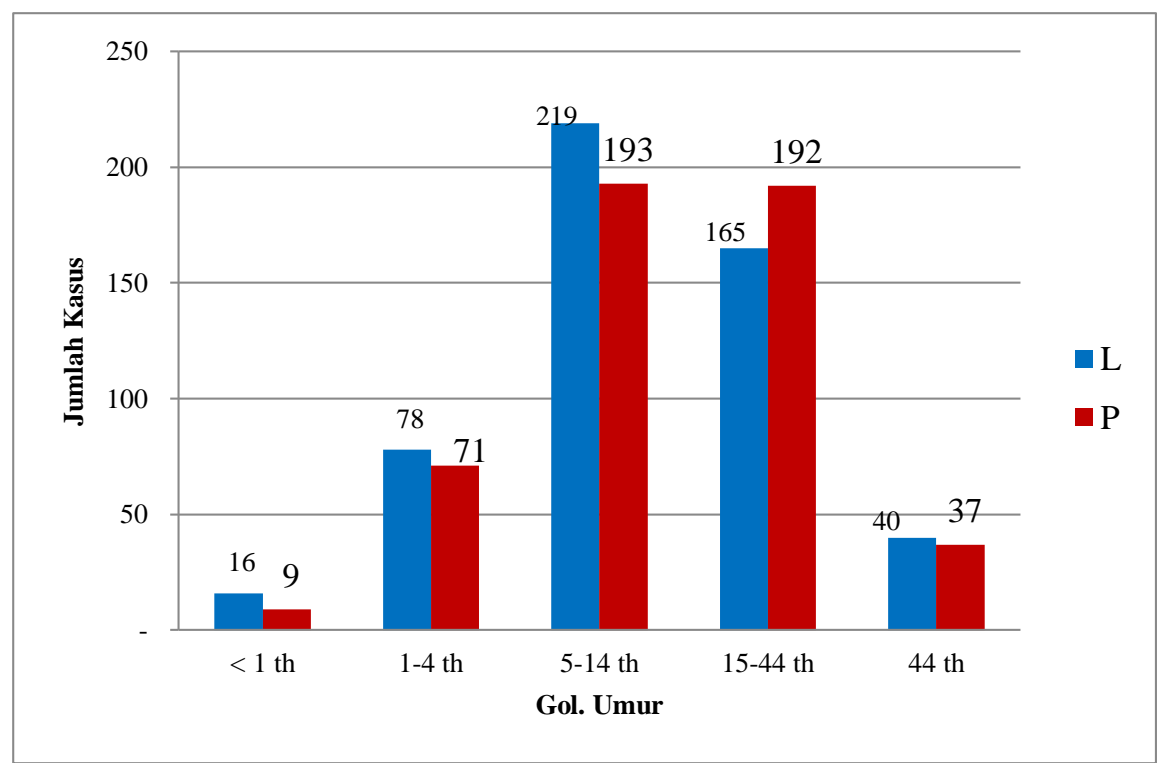

Gambar 5 Grafik Kasus DBD Menurut Golongan Umur dan

Jenis Kelamin di Kota Cimahi Tahun 2019

Diketahui dari 1020 kasus DBD, sebanyak 412 kasus (40,39\%) menyerang golongan usia 5-14 tahun, dan 357 kasus (35\%) usia 15-44 tahun. Hal ini sejalan dengan hasil penelitian di Kota Blitar terjadinya endemic DBD pada tahun 2015-2017 dominan terjadi pada kelompok laki-laki dengan usia 5-14 tahun (Suryani, E.T, 2018).

\section{Program Pencegahan dan Pengendalian DBD di Dinas Kesehatan Kota Cimahi}

Program pencegahan dan pengendalian DBD termasuk ke dalam Program Pencegahan dan Pengendalian Penyakit Menular yang ada di Dinas Kesehatan Kota Cimahi. Kegiatan dalam pelaksanaan yang dilakukan program pencegahan dan pengendalian penyakit DBD antara lain:

1. Pelaporan

Pelaporan diterima Dinas Kesehatan dari masing-masing Puskesmas berdasarkan laporan rutin mingguan dan bulanan serta laporan hasil penyelidikan kasus maupun vektor yang terdiri dari:

a. Data kesakitan dan kematian menurut golongan umur dan jenis kelamin, kasus DD, DBD, EDS dari Unit Pelayanan kesehatan, W1, kewaspadaan mingguan, bulanan, dan tahunan.

b. Data penduduk menurut golongan umur tahunan.

c. Data desa, kecamatan, kabupaten, provinsi terdapat kasus DD, DBD, SSD, EDS bulanan dan tahunan.

d. Data angka bebas jentik (ABJ) kecamatan, kabupaten/kota, provinsi yang dihasilkan dari kegiatan pemantauan jentik.

e. Laporan hasil penyelidikan kasus perorangan. 
Dari hasil laporan tersebut, pemegang program dapat mengetahui tren kejadian serta menentukan strategi atau perencanaan apa yang harus dilakukan dalam pencegahan dan pengendalian DBD di tingkat Kota.

2. Melakukan pemantauan terkait kasus DBD

Pemantauan kasus DBD tersebut dilakukan untuk melihat kecenderungan dari penyakit DBD yang terjadi di Puskesmas berdasarkan data yang tersedia. Pemantauan kasus DBD dilakukan dengan cara menganalisis situasi dengan cara melakukan pengolahan dan penyajian data. Pengolahan dan penyajian data yang dilakukan untuk memantau situasi kasus DD, DBD, EDS bulanan menurut Puskesmas. Pada laporan bulanan tersebut kemudian menghitung jumlah kasus/kematian DD, DBD, EDS termasuk kegiatan pokok pemberantasan/ penanggulangan DBD setiap bulan. Kemudian hasil laporan tersebut akan disampaikan kepada Dinas Kesehatan Provinsi.

Pada hasil analisis data dapat ditentukan stratifikasi daerah endemisitas DBD di tingkat Kecamatan untuk mengetahui wilayah mana saja yang mempunyai kasus DBD tertinggi, sehingga dapat dilakukan penanganan atau pengendalian terfokus dan melakukan penghimbauan kepada wilayah terkait untuk waspada jika memasuki musim akan terjadinya DBD.

3. Menentukan saat terjadinya musim penularan di Puskesmas berdasarkan analisis data DBD yang tersedia

Penentuan saat terjadinya musim penularan dapat dilakukan dengan melihat data cuaca yaitu masuknya musim penghujan. Pemantauan kasus DBD juga dapat dilakukan dengan memprediksi kasus DBD yang akan terjadi di bulan berikutnya dengan menggunakan Laporan dari BMKG Kabupaten/ Kota dan Kecamatan tentang curah hujan, hari hujan, suhu dan kelembaban.

4. Supervisi penyelidikan epidemiologi

Supervisi penyelidikan epidemiologi bersama Dinas kesehatan dilakukan bilamana terjadi atau adanya kasus kematian akibat atau diduga akibat DBD. Hal tersebut dilakukan untuk memastikan apakah kematian tersebut benar-benar diakibatkan oleh DBD atau bukan

5. Pengendalian vektor

Pengendalian vektor yang dilakukan oleh Dinas Kesehatan dapat menggunakan beberapa cara diantaranya: 
a. Pengendalian vektor terpadu

Pengendalian vektor terpadu dilakukan dengan cara melakukan penyuluhan atau pemberian informasi menggunakan berbagai media ataubekerja sama dengan lintas sektor. Salah satunya mengkampanyekan untuk melakukan PSN 3M Plus melalui khotbah Jumat yang dilakukan pada tahun 2019. Selain itu, kegiatan yang dilakukan adalah peningkatan motivasi untuk melaksanakan PSN yaitu lomba PSN tingkat Kecamatan dan Kota

b. Pengendalian sebelum musim penularan

Pengendalian DBD sebelum musim penularan dilakukan oleh pihak Dinas Kesehatan dengan cara menganalisis data kasus DBD dan melakukan prediksi kasus DBD berdasarkan keadaan cuaca. Periode sebelum musim penularan biasanya terjadi sebelum memasuki musim penghujan/ musim penularan DBD. Pengendalian sebelum musim penularan meliputi penyuluhan pada masyarakat, bulan bakti gerakan (BBG) PSN 3M plus secara serentak dan larvasidasi. Bulan Bakti Gerakan (BBG) PSN 3M plus dilaksanakan secara serentak dengan melibatkan kepala daerah, seluruh satuan kerja pemerintah daerah (SKPD) setempat dan seluruh lapisan masyarakat.

c. Pengendalian vektor dengan melaksanakan larvasida dan fogging

Pelaksanaan arvasida biasanya dilaksanakan oleh pihak Puskesmas, sedangkan Dinas Kesehatan hanya memfasilitasi atau menyediakan kebutuhan larvasida yang dibutuhkan pihak Puskesmas jika mengalami kehabisan stok larvasida. Pengendalian vektor dengan fogging dilakukan berdasarkan permintaan dari Puskesmas yang mengindikasikan wilayah tersebut harus dilakukan fogging dari hasil penyelidikan epidemiologi dan adanya kasus.

6. Penanggulangan Kejadian Luar Biasa (KLB) DBD

Penanggulangan KLB DBD dilakukan dengan cara pemutusan rantai penularan atau pemberantasan vektor, membatasi penularan/ penyebaran DBD, sehingga kasus yang terjadi di suatu wilayah tersebut tidak meluas ke wilayah lainnya dengan cara melakukan pengendalian vektor dan mencegah untuk memutus siklus terjadinya KLB. kegiatan tersebut dapat dilakukan dengan pelaksanaan gerakan PSN 3M Plus secara serentak dan evaluasi penanggulangan DBD.

7. Evaluasi Pelaksanaan Penanggulangan DBD

Pemantauan dan evaluasi penggerakan PSN 3M Plus dilaksanakan dengan melakukan pemeriksaan jentik berkala (PJB) pada sejumlah sampel rumah, sekolah dan 
tempat umum lainnya. Indikator keberhasilan penggerakan PSN DBD menggunakan angka bebas jentik $(\mathrm{ABJ}) \geq 95 \%$.

8. Monitoring dan evaluasi hasil penanggulangan DBD

Monitoring dan evaluasi merupakan kegiatan penting dalam upaya pencegahan dan pengendalian demam berdarah. Melalui kegiatan monitoring dan evaluasi dapat dilakukan penilaian terhadap efektivitas dari kegiatan yang sedang dilaksanakan. Penilaian ditujukan untuk mengetahui dampak dari upaya penanggulangan terhadap jumlah penderita atau kasus dan kematian DBD. Tujuan dari evaluasi program yaitu:

1) Menilai kemajuan dan pencapaian program.

2) Mengetahui permasalahan dan penyelesaiannya.

3) Menilai efektivitas dan efisiensi program

4) Untuk mendapatkan arahan alokasi sumber daya

5) Mendapatkan informasi untuk menentukan arah kebijakan dan perencanaan.

9. Kegiatan Pencegahan dan Pengendalian Kasus DBD oleh Dinas Kesehatan Kota Cimahi

a. Penyampaian surat kewaspadaan dini peningkatan kasus DBD ke tiap kecamatan dan kelurahan

b. Himbauan PSN ke Sekolah - Sekolah

c. Penyebaran informasi DBD di Car Free day

d. Penyebaran informasi melalui media sosial

e. Penyebaran informasi melalui khutbah Jumat

f. Penanggulangan fogging fokus DBD

g. Lomba Gertak (Gerakan Serentak) PSN di 15 kelurahan bersama Walikota, Wakil Walikota PJ sekda dan Bimbingan Wilayah SKPD

h. Lomba Gerakan Serentak (Gertak) RW Kami Bebas Jentik di 15 Kelurahan Kota Cimahi.

Berikut kami sajikan tabel hasil analisis perencanaan epidemiologi dari kegiatan pencegahan dan pengendalian DBD melalui pengendalian vektor (fogging) dan lomba PSN melalui gerakan serentak (gertak) rumah kami bebas jentik Kota Cimahi. Program yang dikembangkan bervariasi salah satunya model buku saku dan rapor pemantauan jentik nyamuk dalam meningkatkan perilaku pemberantasan nyamuk sebagai upaya penanggulagan terjadinya endemic DBD (Farasari, R dan Azinar M, 2018). 
Tabel 1. Program Pencegahan dan Pengendalian DBD Melalui Pengendalian Vektor (Fogging) dan Lomba PSN Melalui Gerakan Serentak (Gertak) Rumah Kami Bebas Jentik Kota Cimahi

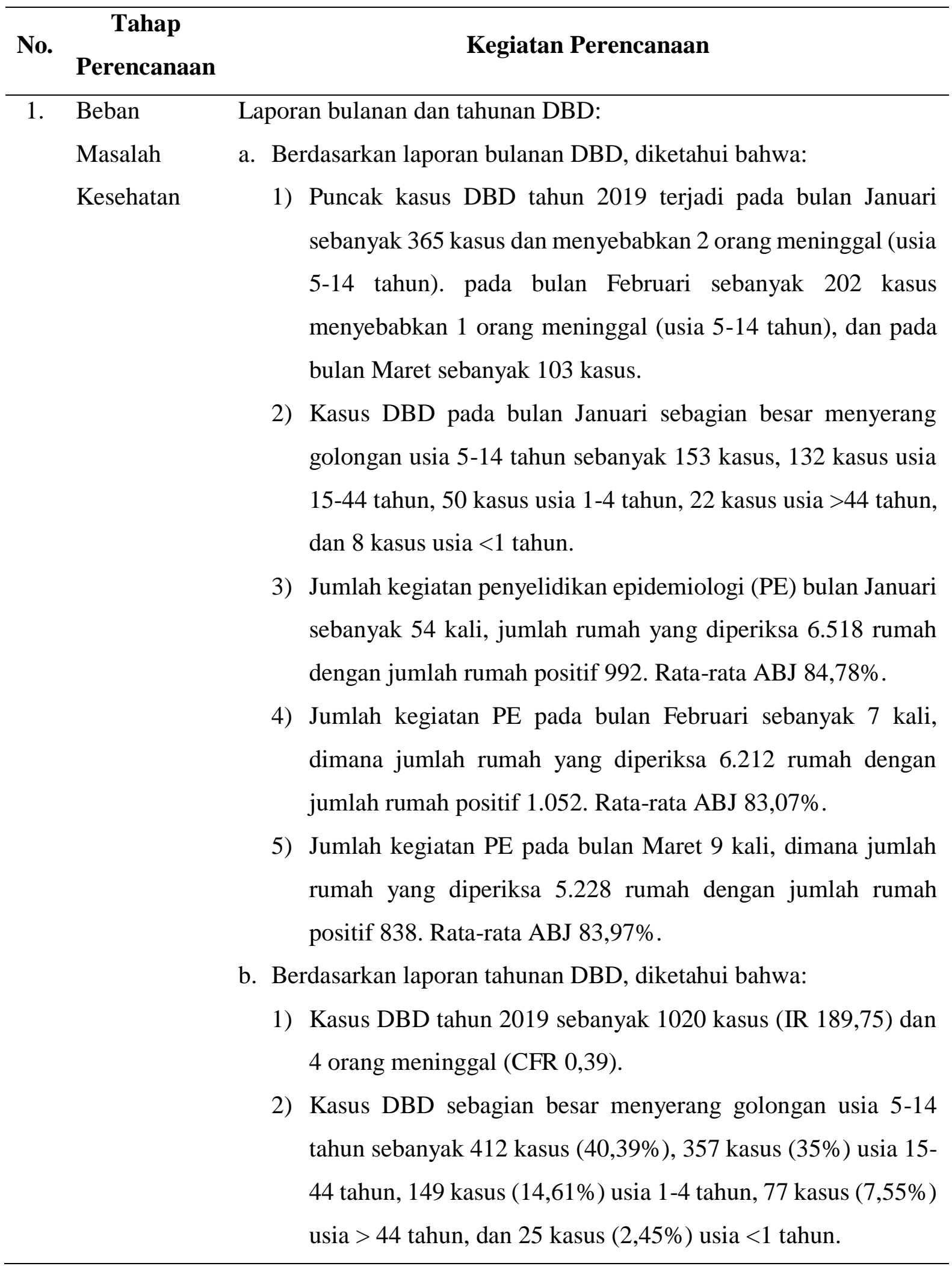


No.

Tahap

Perencanaan

\section{Kegiatan Perencanaan}

3) Jumlah kegiatan PE pada tahun 2019 sebanyak 116 kali, dimana jumlah rumah yang diperiksa 37.077 rumah dengan jumlah rumah positif sebanya 4.061 .

4) Rata-rata angka bebas jentik (ABJ) di Kota Cimahi 89\%, dimana dari 13 Puskesmas yang ada di Kota Cimahi, sebanyak 1 Puskesmas dengan ABJ 95\%, sebanyak 3 Puskesmas dengan ABJ di atas 90-94\% dan 9 Puskesmas lainnya dengan ABJ < $90 \%$.

2. Menjejaki

a. Hasil laporan bulanan dari masing-masing Puskesmas terkait Kausa jumlah kasus, hasil PE dan ABJ.

b. Pelaporan cepat kasus awal DBD

c. Hasil program pencegahan dan pengendalian DBD oleh Dinas Kesehatan Kota Cimahi.

d. Wawancara dengan pemegang program pencegahan dan pengendalian DBD

3. Efektivitas Efektivitas intervensi dari Program Pencegahan dan Pengendalian Intervensi DBD dihitung dengan rumus berikut:

a. Semakin tinggi realisasi menunjukkan pencapaian yang semakin baik, maka digunakan rumus berikut:

Efektivitas $=\frac{\text { Pencapaian }}{\text { Rencana }} \times 100 \%$

b. Semakin tinggi realisasi menunjukkan semakin rendah pencapaian, maka digunakan rumus berikut:

Efektivitas $=\frac{\text { Rencana }-(\text { Pencapaian }- \text { Rencana })}{\text { Rencana }} \times 100 \%$

Indikator Program Pencegahan dan Pengendalian DBD dilihat dari Case Fatality Rate (CFR), incident rate (IR), dan Angka Bebas Jentik $(\mathrm{ABJ})$. Indikator tersebut digunakan sebagai evaluasi perkembangan program. Indikator dibandingkan dengan target yang ditetapkan di Dinkes Kota Cimahi yang mengacu pada target nasional program P2DBD Depkes RI. 


\section{Perencanaan}

\section{Kegiatan Perencanaan}

a. Case Fatality Rate (CFR)

Target Rencana: <1\%; Pencapaian: 0,4\%

Pada indikator ini, semakin tinggi realisasi maka semakin rendah pencapaian, sehingga dapat dihitung efektivitas dari intervensi program P2P DBD berdasarkan CFR sebagai berikut:

Efektivitas $=\frac{\text { Rencana }-(\text { Pencapaian }- \text { Rencana })}{\text { Rencana }} \times 100 \%$

Efektivitas $=\frac{1-(0,4-1)}{1} \times 100 \%$

Efektivitas $=\frac{1,6 \times 100 \%}{1}=160 \%$

Dapat dilihat bahwa efektivitas program ini terhadap CFR adalah $160 \%$.

b. Incident Rate (IR)

Target Rencana: 49 per 100.000 penduduk

Pencapaian: 189,75 per 100.000 penduduk

Pada indikator ini, semakin tinggi realisasi menunjukkan semakin rendah pencapaian, maka dapat dihitung efektivitas dari intervensi program pencegahan dan pengendalian DBD berdasarkan IR sebagai berikut:

Efektivitas $=\frac{\text { Rencana }-(\text { Pencapaian }- \text { Rencana })}{\text { Rencana }} \times 100 \%$

Efektivitas $=\frac{49-(189,75-49)}{49} \times 100 \%$

Efektivitas $=\frac{-91,75 \times 100 \%}{49}=-187,24 \%$

Dapat dilihat bahwa efektivitas program ini terhadap IR adalah $187,24 \%$. Terjadinya minus pada program ini karena adanya akumulasi, sehingga dalam hal ini dilihat efektivitas program berdasarkan IR per bulannya.

c. Angka Bebas Jentik (ABJ).

Target Rencana: >95\%; Pencapaian: 89\%

Pada indikator ini, semakin tinggi realisasi maka pencapaian yang semakin baik. Dapat dihitung efektivitas dari intervensi program 
No. Tahap

\section{Kegiatan Perencanaan}

pencegahan dan pengendalian DBD berdasarkan ABJ sebagai berikut:

Efektivitas $=\frac{\text { Pencapaian }}{\text { Rencana }} \times 100 \%$

Efektivitas $=\frac{89}{95} \times 100 \%=93,68 \%$

Dapat dilihat bahwa efektivitas program ini terhadap ABJ adalah $93,68 \%$.

4. Efisiensi Pembiayaan yang didapatkan untuk Program Pengendalian DBD berasal dari dana BOK APBD sebesar Rp 173.140.000,- yang dibagi menjadi dua 2 (dua) kegiatan yaitu:

a. Kegiatan Fogging sebesar Rp 138.425.000,-

b. Lomba PSN sebesar Rp 34.725.000,-

Rumus menghitung efisiensi yaitu:

Efisiensi $=\frac{\text { Output }}{\text { Input }} \times 100 \%$

Output $=\frac{\text { Hasil }(\text { Kenyataan }) \text { Pencapaian Tujuan }}{\text { Pengeluaran Sebenarnya }} \times 100 \%$

Input $=\frac{\text { Target }(\text { Rencana }) \text { Pencapaian Tujuan }}{\text { Rencana Pembiayaan }} \times 100 \%$

Berdasarkan rumus di atas, dapat dihitung efisiensi dari program pencegahan dan pengendalian DBD terhadap CFR, IR, dan ABJ sebagai berikut:

a. Efisiensi program pencegahan dan pengendalian DBD dilihat dari indikator CFR DBD

$$
\begin{aligned}
& \text { Output }=\frac{0,4}{173.150 .000} \times 100 \%=0,0000002 \% \\
& \text { Input }=\frac{1}{173.150 .000} \times 100 \%=0,0000005 \% \\
& \text { Efisiensi }=\frac{0,0000002}{0,0000005} \times 100 \%=40 \%
\end{aligned}
$$

Dapat dilihat efisiensi program ini terhadap indikator CFR DBD adalah $40 \%$. 
Tahap

\section{Perencanaan}

\section{Kegiatan Perencanaan}

b. Efisiensi program pencegahan dan pengendalian DBD dilihat dari indikator IR DBD

$$
\begin{aligned}
& \text { Output }=\frac{189,75}{173.150 .000} \times 100 \%=0,0000999 \% \\
& \text { Input }=\frac{49}{173.150 .000} \times 100 \%=0,0000258 \% \\
& \text { Efisiensi }=\frac{0,0000999}{0,0000258} \times 100 \%=387,2 \%
\end{aligned}
$$

Dapat dilihat bahwa efisiensi program ini terhadap indikator IR DBD adalah $387,2 \%$.

c. Efisiensi program pencegahan dan pengendalian DBD dilihat dari indikator ABJ DBD

$$
\begin{aligned}
& \text { Output }=\frac{89}{173.150 .000} \times 100 \%=0,0000468 \% \\
& \text { Input }=\frac{95}{173.150 .000} \times 100 \%=0,0000500 \% \\
& \text { Efisiensi }=\frac{0,0000468}{0,0000500} \times 100 \%=93,68 \%
\end{aligned}
$$

Dapat dilihat bahwa efisiensi program ini terhadap dari indikator ABJ DBD adalah 93,68\%.

5. Implementasi

a. Pelaporan kasus mingguan dan bulanan DBD dari masing-masing Puskesmas dan pelaporan langsung dari petugas Puskesmas

b. Hasil penyelidikan epidemiologi dilakukan setelah menerima laporan adanya penderita DBD. Kegiatan ini dilakukan untuk mencari penderita DBD dan tersangka DBD lainnya diikuti dengan kegiatan pemeriksaan jentik nyamuk penular DBD di 20 rumah sekitar tempat tinggal penderita atau dalam radius 100 meter baik di dalam maupun di luar rumah.

c. Pelaksanaan lomba PSN “Gerakan Serentak (Gertak) Rumah kami Bebas Jentik" adapun kegiatannya yaitu:

1) Membuat perencanaan kegiatan lomba dan surat keputusan Walikota

2) Membuat sistematika program kegiatan lomba 
No.

Tahap

Perencanaan

\section{Kegiatan Perencanaan}

3) Mengumpulkan seluruh kepala desa, camat, dan pihak Puskesmas sebagai peserta dan panitia lomba

4) Menjelaskan mekanisme lomba serta syarat lomba

5) Membagi panitia pengawas dalam lomba yang dilakukan oleh pihak Puskesmas yang dilakukan secara acak.

6) Membagi wilayah RW mana yang akan dijadikan atau ikut serta dalam lomba

7) Pelaksanaan lomba

8) Penilaian hasil lomba

9) Pengumuman pemenang hasil lomba

d. Pelaksanaan fogging sebanyak 2 siklus dengan interval 1 minggu jika ditemukan 1 kasus di daerah yang belum terkena DBD atau wilayah dengan peningkatan kasus DBD yang signifikan setelah dilakukan PSN, dimana pelaksanaan foging dilakukan berdasarkan permintaan dari pihak Puskesmas.

6. Monitoring Monitoring program DBD dengan melihat kasus, IR, kematian, ABJ, rumah positif jentik pada masing-masing Puskesmas yang dilakukan tiap bulan dari hasil laporan.

7. Reassesment Evaluasi program DBD berdasarkan indikator keberhasilan, yaitu:

a. Adanya penurunan jumlah kasus dan IR DBD dibandingkan bulan yang sama di tahun sebelumnya, bulan sebelumnya di tahun yang sama, bulan berikutnya di tahun yang sama, dan dibandingkan tahun sebelumnya serta tidak adan kasus kematian akibat DBD pada masing-masing wilayah Puskesmas di Kota Cimahi.

b. Adanya penurunan angka rumah positif bebas jentik dibandingkan bulan yang sama di tahun sebelumnya, bulan sebelumnya di tahun yang sama, bulan berikutnya di tahun yang sama, dan dibandingkan tahun sebelumnya pada masing-masing Puskesmas Kota Cimahi. 


\section{Tahap \\ Perencanaan \\ Kegiatan Perencanaan}

c. Adanya peningkatan nilai $\mathrm{ABJ}$ dibandingkan bulan yang sama di tahun sebelumnya, bulan sebelumnya di tahun yang sama, bulan berikutnya di tahun yang sama, dan dibandingkan tahun sebelumnya pada masing-masing Puskesmas Kota Cimahi.

d. Puskesmas melaksanakan pelaporan rutin dan tepat waktu yaitu 1 bulan 2 kali.

e. Mengaktifkan dan mengefektifkan kembali program Jumantik serta kader Jumatik di setiap RT dan RW di masing-masing wilayah kerja Puskesmas di Kota Cimahi.

f. Mengefektifkan kegiatan Jumat bersih "Jumsih" atau minggu bersih sebagai bentuk gerakan PSN masyarakat yang dapat dilakukan setiap minggu.

\section{KESIMPULAN DAN SARAN}

Hasil penjajakan masalah dengan menganalisis situasi kasus DBD bahwa kasus DBD tahun 2019 masih sangat tinggi yang mencapai 1020 kasus, dengan IR 189,75 per 100.000 penduduk (target nasional<49\%), dan persentase ABJ 89\% (target nasional >95\%). Efektivitas intervensi pada program pencegahan dan pengendalian DBD terhadap CFR DBD adalah 160\%. Efektivitas program terhadap IR DBD adalah $-187,24 \%$. Efektivitas program terhadap keberhasilan ABJ adalah 93,68\%.Efisiensi dari program pencegahan dan pengendalian DBD terhadap CFR DBD adalah 40\%. Efisiensi program terhadap IR DBD adalah 387,2\%. Efisiensi program terhadap keberhasilan ABJ adalah 93,68\%. Implementasi program pencegahan dan pengendalian DBD diantaranya hasil pelaporan bulan, hasil penyelidikan epidemiologi, Pelaksanaan lomba PSN “Gerakan Serentak (Gertak) Rumah kami Bebas Jentik", dan pelaksaan fogging. Adapun saran yang dapat kami sampaikan terkait dari hasil pengabdian ini, diantaranya:

1. Dapat menyediakan alat diagnosis awal DBD seperti Rapid Test Diagnostik (RTD) atau NS1 pada masing-masing Puskesmas sebagai salah satu diagnosis awal DBD.

2. Dapat membuat sistem pelaporan kasus yang sama dan berjenjang antara Dinas Kesehatan, Rumah Sakit dan Puskesmas untuk menyamakan laporan dengan instansi.

3. Dapat terus melakukan program PSN secara serentak yang dalam jangka panjang akan meningkatkan kebiasaan masyarakat dalam melakukan PSN. 
4. Disarankan agar membuat inovasi program dalam usaha meningkatkan minat dan kebiasaan masyarakat dalam melakukan PSN.

\section{UCAPAN TERIMA KASIH}

Kami mengucapkan terima kasih kepada:

1. Ketua Stikes Jenderal Achmad Yani Cimahi karena telah memberikan kesempatan untuk melaksanakan kegiatan ini; dan

2. kepada pegawai Dinas Kesehatan Kota Cimahi yang telah bekerjasama melaksanakan kegiatan ini.

\section{DAFTAR PUSTAKA}

Arsin, A. A. (2013). Epidemiologi Demam Berdarah (DBD) Di Indonesia (A. Sade, ed.). Makassar: Masagena Press.

Chin, J. (2012). Manual Pemberantasan Penyakit Menular (17 ed.; J. Chin, ed.; I. N. Kandun, penerj.). Jakarta: Infomedika.

Depkes RI. (2010). Surveilans Epidemiologi Demam Berdarah Dengue. Jakarta: Ditjen P2PL.

Dinkes Jawa Barat. (2018). Profil Kesehatan Provinsi Jawa Barat Tahun 2017. Bandung: Dinas Kesehatan Provinsi Jawa Barat.

Dinkes Kota Cimahi. (2018). Profil Kesehatan Cimahi 2017. Cimahi: Dinas Kesehatan Kota Cimahi.

Dinkes Kota Cimahi. (2019). Situasi DBD Di Kota Cimahi Tahun 2018-2019. Cimahi: Bidang P2P Dinas Kesehatan Kota Cimahi.

Djunaedi, D. (2006). Demam Berdarah [Dengue DBD] Epidemiologi, Imunopatologi, Patogenesis, Diagnosis dan Penatalaksanaannya. Malang: UMM Press.

Hadinegoro, S., Soegijanto, S., Wuryadi, S., Seroso T. (2001). Tatalaksana Demam Berdarah Dengue Di Indonesia. Jakarta: Depkes RI.

Kemenkes RI. (2017a). Buku Pedoman: Penyeldikan dan Penanggulangan Kejadian Luar Biasa Penyakit Menular dan Keracunan Makanan (Pedoman Epidemiologi Penyakit) Edisi Revisi 2017 (Puhilan, ed.). Jakarta: Subdit Surveilans; Direktorat Surveilans Dan Karantina Kesehatan; Dirjen P3L; Kemenkes RI.

Kemenkes RI. (2017b). Pedoman Pencegahan dan Pengendalian Demam Berdarah Dengue di Indonesia. Jakarta: Kemenkes RI Dirjen P2P.

Kemenkes RI. (2019). Profil Kesehatan Indonesia 2018. Jakarta: Kementerian Kesehatan Republik Indonesia. 
Purnama, S. G. (2017). Diktat Kuliah Penyakit Berbasis Lingkungan. Bali: Program Studi Ilmu Kesehatan Masyarakat Universitas Udayana.

Qi, X., Wang, Y., Li, Y., Meng, Y., Chen, Q., \& Ma, J. (2015). The Effects of Socioeconomic and Environmental Factors on the Incidence of Dengue Fever in the Pearl River Delta, China. PLOS Neglected Tropical, 9(10), 1-13. https://doi.org/10.1371/journal.pntd.0004159

Farasari, R., Azinar, M. (2018). Model Buku Saku dan Rapor Pemantauan Jentik dalam Meningkatkan Perilaku Pemberantasan Sarang Nyamuk. Jurnal of Health Educationa. 3(2), 110-117. http://journal.unnes.ac.id/sju/index.php/jhealthedu

Setiati, S., Alwi, I., Sudoyo, A. W., Simadibrata, M., Setiyohadi, B., \& Syam, A. F. (2014). Buku Ajar Ilmu Penyakit Dalam. In S. Setiati, I. Alwi, A. W. Sudoyo, M. S. K, B. Setiyohadi, \& A. F. Syam (Ed.), Buku Ajar Ilmu Penyakit Dalam (Keenam). Jakarta: Interna Publishing. Suryani, E.T (2018). Gambaran Kasus Demam Berdarah Dengue di Kota Blitar. Jurnal Berkala Epidemiologi, 6(3), 261-267. https://jurnal unair.ac.id/index.php/JBE/. 